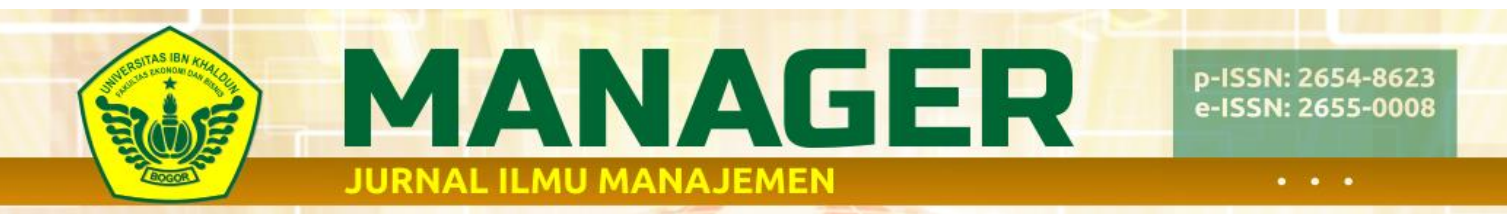

Vol. 2, No. 2, Mei 2019, Hal 97-108 (c) (1) () http://ejournal.uikabogor.ac.id/index.php/Manager/index

\title{
MENGUKUR KINERJA KEUANGAN PERUSAHAAN DENGAN MENGGUNAKAN METODE DU PONT
}

\author{
Sobari, Titing Suharti dan Supramono \\ titing@gmail.com supramonouika@gmail.com
}

\section{Fakultas Ekonomi dan Bisnis Universitas Ibn Khaldun Bogor,Indonesia}

\begin{abstract}
Abstrak
Tujuan penelitian ini adalah untuk mengetahui bagaimana kinerja keuangan perusahaan yang bergerak di sektor farmasi jika diukur dengan menggunakan metode $D u$ Pont. Sampel pada penelitian ini terdiri dari 3 perusahaan, yaitu PT. Kalbe Farma Tbk, PT. Kimia Farma Tbk, dan PT. Darya-Varia Laboratoria Tbk selama periode tahun 2013-2017. Sampel dipilih menggunakan metode purposive sampling. Metode analisis data yang digunakan adalah metode analisis $D u$ Pont dimana didalamnya terdapat beberapa rasio keuangan yang dipakai dalam penelitian ini diantaranya adalah Total Asset Turn Over, Net Profit Margin, Return On Investment, Equity Multiplier dan Return On Equity. Hasil penelitian ini menunjukan bahwa PT. Kalbe Farma Tbk memiliki tingkat pengembalian terhadap modal nya lebih baik dengan rata-rata ROE sebesar 19,99\%, sedangkan PT. Kimia Farma Tbk memperoleh rata-rata ROE sebesar 12,05\% dan PT. Darya-Varia Laboratoria Tbk memperoleh rata-rata ROE sebesar 12,44\%. Hal ini menunjukan bahwa PT. Kalbe Farma Tbk lebih unggul dibandingkan dengan dua perusahaan lainnya.
\end{abstract}

Kata Kunci : Asset Turn Over, Net Profit Margin, Return On Investment, Equity Multiplier, Return On Equity,

\section{Abstrack}

The purpose of this study is to find out how the financial performance of companies engaged in the pharmaceutical sector if measured using the Du Pont method. The sample in this study consists of 3 companies, namely PT. Kalbe Farma Tbk, PT. Kimia Farma Tbk, and PT. Darya-Varia Laboratoria Tbk during the period of 2013- 
2017. The sample was chosen using purposive sampling method. Data analysis method used is Du Pont analysis method wherein there are some financial ratios used in this research are Total Asset Turn Over, Net Profit Margin, Return On Investment, Equity Multiplier and Return On Equity. The results of this study showed that PT. Kalbe Farma Tbk has a better return on capital with an average ROE of 19.99\%, while PT. Kimia Farma Tbk obtained an average ROE of $12.05 \%$ and PT. Darya-Varia Laboratoria Tbk obtained an average ROE of $12.44 \%$. This shows that PT. Kalbe Farma Tbk is superior to two other companies.

Keyword : Asset Turn Over, Net Profit Margin, Return On Investment, Equity Multiplier, Return On Equity, and Financial Performance.

\section{I}

. Pendahuluan

\section{Latar Belakang}

Perkembangan dalam dunia perekonomian semakin berkembang pesat, banyak perusahaan-perusahaan di dunia yang didirikan berlomba untuk menjadi perusahaan yang unggul agar lebih kompetitif, hanya perusahaan yang unggul dan kompetitiflah yang dapat bertahan dalam persaingan perekonomian didunia yang semakin ketat.

Masalah keuangan adalah termasuk salah satu masalah yang sangat penting dalam suatu perusahaan dan perkembangan bisnis di semua perusahaan. Perusahaan didirikan dengan tujuan utamanya yaitu untuk mendapatkan keuntungan yang maksimal. Namun berhasil tidak nya perusahaan mendapatkan keuntungan dan mempertahankan perusahaannya tergantung pada manajemen keuangan. Perusahaan harus memiliki kinerja yang sehat dan efisien untuk mendapatkan laba. Oleh karena itu, kinerja keuangan merupakan hal yang penting untuk perusahaan mempertahankan dan mengembangkan perusahaannya.

Kinerja keuangan merupakan suatu analisis yang dilakukan untuk melihat sejauh mana suatu perusahaan telah melaksanakan dengan menggunakan aturan-aturan pelaksanaan keuangan secara baik dan benar. Kinerja keuangan menjadi hal yang sangat penting, karena kinerja keuangan dapat dijadikan sebagai gambaran bahwa perusahaan dalam keadaan baik atau sebaliknya. Jika memiliki kinerja keuangan yang baik hal itu bisa menjadi tolak ukur untuk setiap investor atau pemegang saham untuk menanamkan dananya kedalam perusahaan.

Untuk mengukur kinerja keuangan perusahaan digunakan alat analisis yaitu analisis Du Pont. Analisis Du Pont adalah suatu analisis yang memusatkan analisis pada bagaimana meningkatkan ROE (return on equity). Semakin tinggi ROE suatu perusahaan berarti semakin baik pula kinerja keuangan perusahaan tersebut. Analisis Du Pont penting bagi seorang manajer karena dengan analisis ini dapat 
dilihat faktor mana yang paling kuat pengaruhnya antara profit margin dan total asset turn over terhadap ROI. Dengan menggunakan analisis Du Pont ini juga pengendalian biaya dan efisiensi perputaran aktiva juga dapat diukur. Mengukur analisis Du Pont ini diperlukan banyak rasio antara lain asset turn over, net profit margin, return on investment, equity multiplier dan return on equity. Jadi dapat disimpulkan bahwa analisis Du Pont ini mencakup semua aktivitas yang dilakukan perusahaan.

Analisis Du Pont memiliki keunggulan dan kelemahan. Keunggulan Du Pont antara lain analisis Du Pont merupakan salah satu teknik analisis keuangan yang sifatnya menyeluruh dan manajemen bisa mengetahui tingkat efisiensi pendayagunaan aktiva. Du Pont juga dapat digunakan untuk mengukur profitabilitas masing-masing produk yang dihasilkan perusahaan sehingga diketahui produk perusahaan yang potensial. Kelemahan Du Pont salah satunya adalah bahwa ROI suatu perusahaan sulit dibandingkan dengan ROI perusahaan lain yang sejenis. Hal ini karena adanya perbedaan praktik akuntansi yang digunakan.

Untuk menganalisis kinerja keuangan perusahaan diperlukan laporan keuangan. Laporan keuangan adalah suatu informasi yang menggambarkan kondisi keuangan suatu perusahaan dan dapat dijadikan juga sebagai gambaran kinerja keuangan tersebut. Bentuk laporan keuangan yang digunakan untuk analisis $\mathrm{Du}$ Pont ini adalah neraca dan laporan laba rugi.

Sobari, Titing Suharti dan Supramono
Neraca adalah laporan yang sistematis tentang aktiva, hutang serta modal dari suatu perusahaan pada suatu saat tertentu. Sedangkan laporan laba rugi adalah bentuk laporan keuangan yang menyajikan pendapatan, biaya, dan laba perusahaan dalam periode tertentu. Kedua bentuk laporan keuangan tersebut sangat diperlukan untuk alat analisis ini. Dalam hal ini akan dilakukan penelitian dengan menggunakan metode analisis Du Pont pada perusahaan yang bergerak di sektor farmasi, yaitu PT. Kalbe Farma Tbk, PT. Kimia Farma Tbk, dan PT. Darya-Varia Laboratoria Tbk. Diantara ketiga perusahaan sektor farmasi ini dapat dilihat perusahaan mana yang memiliki kinerja keuangan yang sangat baik jika diukur menggunakan metode Du Pont.

Berdasarkan uraian latar belakang diatas dapat diambil judul "Mengukur Kinerja Keuangan Perusahaan dengan Menggunakan Metode Du Pont Pada Perusahaan Sektor Farmasi yang Terdaftar di Bursa Efek Indonesia (BEI) Periode 2013 - 2017 ( Studi Kasus Pada PT. Kalbe Farma Tbk, PT. Kimia Farma Tbk, dan PT. Darya Varia Laboratoria Tbk )".

\section{Perumusan Masalah}

Berdasarkan latar belakang masalah dan identifikasi masalah, maka dapat dirumuskan masalah yaitu: Bagaimana kinerja keuangan PT. Kalbe Farma Tbk, PT. Kimia Farma Tbk, dan PT. DaryaVaria Laboratoria Tbk jika diukur menggunakan metode Du Pont?

\section{Tujuan dan Manfaat Penelitian}

Jurnal Manager Vol. 2, No. 2, Mei 2019| 97 
Tujuan penelitian ini adalah untuk mengetahui kinerja keuangan perusahaan PT. Kalbe Farma Tbk, PT. Kimia Farma Tbk, dan PT. Darya-Varia Laboratoria Tbk yang diukur menggunakan metode DuPont.

\section{Metode Penelitian}

\section{Jenis Penelitian}

Jenis data yang digunakan dalam penelitian ini adalah data Kuantitatif. Menurut (M. Azis Firdaus, 2016:29) "Data kuantitatif merupakan data yang berbentuk angka (numeric)". Data ini diperoleh dari laporan keuangan yang dipublikasikan di Bursa Efek Indonesia yaitu PT Kalbe Fama Tbk, PT Kimia
Farma Tbk, dan PT Darya-Varia Laboratoria Tbk selama periode 20132017.

2. Populasi dan Teknik Pengambilan Sampel

Populasi yang akan menjadi objek penelitian ini yaitu perusahaan yang bergerak di sektor farmasi yang terdaftar dan telah melakukan pelaporan keuangannya di Bursa Efek Indonesia (BEI) selama periode tahun 2013-2017.

Adapun perusahaan-perusahaan tersebut adalah sebagai berikut :

\section{Tabel 1}

\section{Populasi Perusahaan Sektor Farmasi}

\begin{tabular}{ccc}
\hline No & Kode Efek & Nama Emiten \\
\hline 1 & DVLA & Darya Varia Laboratoria Tbk \\
\hline 2 & INAF & Indofarma Tbk \\
\hline 3 & KAEF & Kimia Farma (persero) Tbk \\
\hline 4 & KLBF & Kalbe Farma Tbk \\
\hline 5 & MERK & Pyridam Farma Tbk \\
\hline 6 & PYFA & Merck Sharp Dohme Pharma Tbk \\
\hline 7 & SCPI & Industri Jamu \& Farmasi Sido Muncul Tbk \\
\hline 8 & SIDO & Taisho Pharmaceutical Indonesia Tbk (Saham Biasa) \\
\hline 9 & SQBB & Taisho Pharmaceutical Indonesia Tbk (Saham Preferen) \\
\hline & SQBI & Tempo Scan Pasific Tbk \\
\hline 10 & TSPC &
\end{tabular}

Sampel merupakan sebagian dari anggota populasi yang memiliki karakteristik populasi. Penentuan sampel penelitian berdasarkan pertimbangan-pertimbangan sebagai berikut :
1. Perusahaan berturut-turut terdaftar di Bursa Efek Indonesia pada tahun 2013, 2014, 2015, 2016, dan 2017.

2. Memiliki satu emiten sampel yang dikelola oleh Badan Usaha Milik Negara (BUMN) 
3. Memiliki dua emiten sampel yang dikelola oleh Swasta.
4. Perusahaan konsisten menerbitkan laporan keuangan setiap tahun.

Tabel 2

\section{Perusahaan yang menjadi Sampel Penelitian}

\begin{tabular}{ccc}
\hline No & Kode Efek & Nama Emiten \\
\hline 1 & KLBF & PT. Kalbe Farma Tbk. \\
\hline 2 & KAEF & PT. Kimia Farma Tbk. \\
\hline 3 & DVLA & PT. Darya-Varia Laboratoria Tbk. \\
\hline
\end{tabular}

3. Teknik Analisis Data

Dalam pengumpulan data dilakukan dengan cara studi pustaka (Library research), yaitu membaca laporan tahunan (annual report) perusahaan dan literatur, tulisan ilmiah yang terdapat di perpustakaan seperti buku-buku yang ditulis oleh para ahli dibidangnya, yang berhubungan dengan objek penelitian. Teknik dokumentasi yaitu pengumpulan data yang dilakukan dengan mencari data mengenai hal-hal atau variabel yang berupa catatan atau data-data yang sudah dipublikasikan oleh perusahaan yang terdaftar di Bursa Efek Indonesia (BEI).

\section{Hasil dan Pmbahasan}

\section{Analisis Du Pont Pada PT. Kalbe Farma Tbk, PT. Kimia Farma Tbk, dan PT. Darya-Varia Laboratoria Tbk.}

Untuk mengetahui sejauh mana kinerja keuangan perusahaan pada PT. Kalbe Farma Tbk, PT. Kimia Farma Tbk, dan PT. Darya-Varia Laboratoria Tbk, maka berikut ini perhitungan dengan menggunakan analisis Du Pont yang komponen-komponen perhitungannya berasal dari laporan keuangan (Neraca dan Laba Rugi).

\section{Asset Turn Over}

Menurut Arief Sugiono dan Edy Untung (2016:75) "Asset Turn Over adalah kemampuan perusahaan dalam mengelola seluruh aset/investasi untuk menghasilkan penjualan".

$$
\text { Asset Turn Over }=\frac{\text { penjualan }}{\text { Total Aktiva }} \times 1 \text { kali }
$$

Tabel 3

Asset Turn Over Sampel Perusahaan

\begin{tabular}{ccccccc}
\hline Nama Perusahaan & 2013 & 2014 & 2015 & 2016 & 2017 & Rata-Rata \\
\hline PT. Kalbe Farma Tbk & $211 \mathrm{Kali}$ & $1,40 \mathrm{Kali}$ & $1,31 \mathrm{Kali}$ & $1,37 \mathrm{Kali}$ & $1,21 \mathrm{Kali}$ & 1,34 Kali \\
\hline PT. Kimia Farma Tbk & $1,76 \mathrm{Kali}$ & $1,52 \mathrm{Kali}$ & $1,50 \mathrm{Kali}$ & $1,26 \mathrm{Kali}$ & $1,00 \mathrm{Kali}$ & $1,41 \mathrm{Kali}$ \\
$\begin{array}{c}\text { 'T. Darya-Varia Laboratoria } \\
\text { Tbk }\end{array}$ & $0,93 \mathrm{Kali}$ & $0,89 \mathrm{Kali}$ & $0,95 \mathrm{Kali}$ & $0,95 \mathrm{Kali}$ & $0,96 \mathrm{Kali}$ & 0,94 Kali \\
\hline
\end{tabular}


Sumber : Data diolah

Berdasarkan analisis sistem du pont selama 5 tahun yaitu periode tahun 2013 2017, PT. Kalbe Farma Tbk mampu menghasilkan asset turn over rata-rata 1,34 kali, sedangkan PT Kimia Farma Tbk mampu menghasilkan asset turn over ratarata 1,41 kali dan PT. Darya Varia Laboratoria mampu menghasilkan asset turn over rata-rata 0,94 kali, yang dimiliki perusahaan secara efisien untuk menghasilkan penjualan dari total aktiva yang dimiliki. Jika dilihat dari kemampuan perusahaan mengelola total aktiva menjadi penjualan PT. Kimia Farma Tbk lebih unggul dibandingkan dengan perusahaan lainnya.

\section{Grafik 1}

\section{Perubahan Asset Turn Over Sampel Perusahaan}

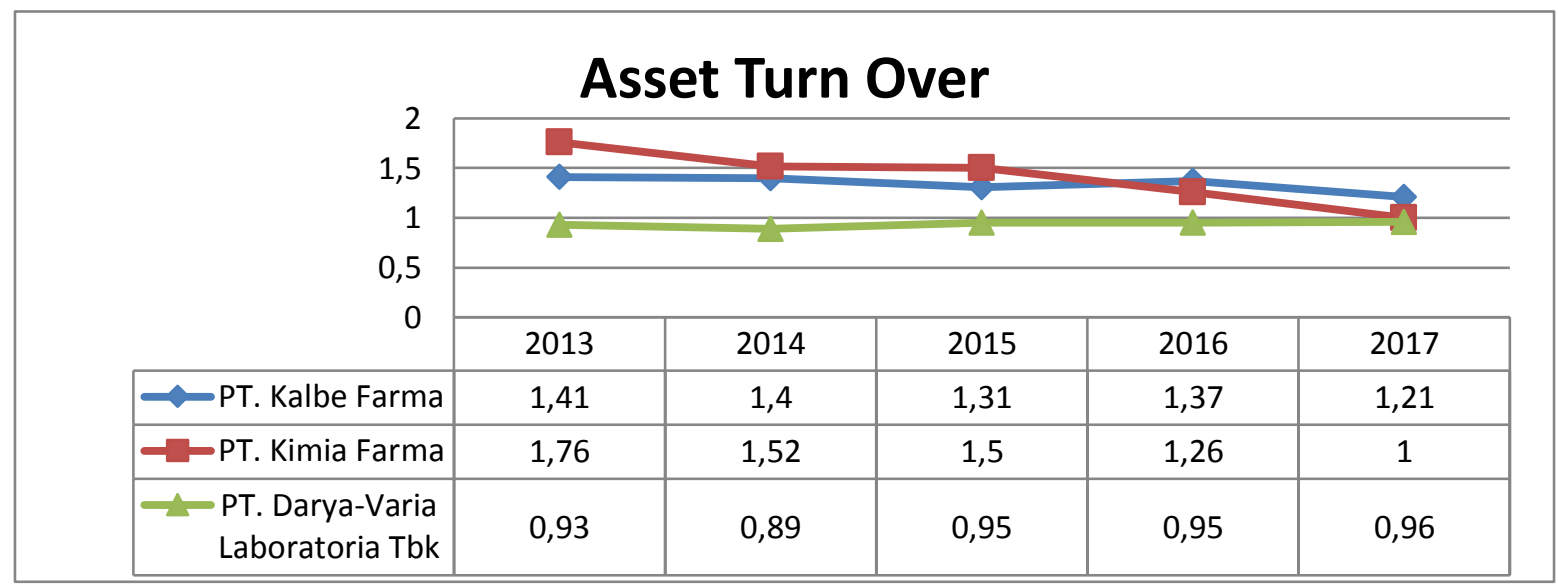

Sumber : Data diolah

\section{Net Profit Margin}

Menurut Arief Sugiono dan Edi Untung (2016:75)
"Net

Profit menunjukan berapa besar keuntungan bersih yang diperoleh perusahaan".

$$
\text { Net Profit margin }=\frac{\text { Laba Bersih }}{\text { Penjualan }} \times 100 \%
$$

Tabel 4

\section{Net Profit Margin Sampel Perusahaan}

\begin{tabular}{|c|c|c|c|c|c|c|}
\hline Nama Perusahaan & 2013 & 2014 & 2015 & 2016 & 2017 & Rata-Rata \\
\hline PT. Kalbe Farma Tbk & $12,31 \%$ & $12,22 \%$ & $11,50 \%$ & $12,13 \%$ & $12,15 \%$ & $12,06 \%$ \\
\hline PT. Kimia Farma Tbk & $4,96 \%$ & $5,23 \%$ & $5,20 \%$ & $4,67 \%$ & $5,41 \%$ & $5,10 \%$ \\
\hline PT. Darya-Varia Laboratoria Tbk & $11,42 \%$ & $7,39 \%$ & $8,26 \%$ & $10,48 \%$ & $10,30 \%$ & $9,57 \%$ \\
\hline
\end{tabular}


Sumber : Data diolah

Berdasarkan hasil analisis sistem du pont selama periode tahun 2013 - 2017 PT. Kalbe Farma Tbk mampu menghasilkan laba bersih setelah pajak dari volume penjualan dengan rata-rata net profit margin sebesar 12,06\%, PT. Kimia Farma Tbk mampu menghasilkan laba bersih setelah pajak dari volume penjualan dengan rata-rata net profit margin sebesar 5,10\% sedangkan untuk
PT. Darya Varia Laboratoria Tbk mampu menghasilkan laba bersih setelah pajak dari volume penjualan dengan rata-rata net profit margin sebesar 9,57\%. Jika dilihat dari kemampuan ketiga perusahaan tersebut, PT Kalbe Farma Tbk lebih unggul dibandingkan dengan perusahaan lainnya.

\section{Grafik 2}

Perubahan Net Profit Margin Sampel Perusahaan

\begin{tabular}{|c|c|c|c|c|c|}
\hline $\begin{array}{l}15,00 \% \\
10,00 \%\end{array}$ & \multicolumn{5}{|c|}{$\mathrm{rar}$} \\
\hline \multicolumn{6}{|l|}{$5,00 \%$} \\
\hline $0,00 \%$ & 2013 & 2014 & 2015 & 2016 & 2017 \\
\hline$\leadsto$ PT. Kalbe Farma & $12,31 \%$ & $12,22 \%$ & $11,50 \%$ & $12,13 \%$ & $12,15 \%$ \\
\hline- PT. Kimia Farma & $4,96 \%$ & $5,23 \%$ & $5,20 \%$ & $4,67 \%$ & $5,41 \%$ \\
\hline $\begin{array}{l}\text { PT. Darya-Varia } \\
\text { I ahoratoria Thk }\end{array}$ & $11,42 \%$ & $7,39 \%$ & $8,26 \%$ & $10,48 \%$ & $10,30 \%$ \\
\hline
\end{tabular}

Sumber : Data diolah

3. Return On Investment

rasio yang mengukur tingkat pengembalian Menurut Arief Sugiono dan Edi Untung dari bisnis atas seluruh asset yang ada". (2016:75) "Return on investment adalah

$$
\text { ROI = Net Profit Margin } x \text { Asset Turn }
$$

Tabel 5

Return On Investment Sampel Perusahaan

\begin{tabular}{|c|c|c|c|c|c|c|}
\hline Nama Perusahaan & 2013 & 2014 & 2015 & 2016 & 2017 & Rata-Rata \\
\hline PT. Kalbe Farma Tbk & $17,36 \%$ & $17,11 \%$ & $15,10 \%$ & $15,40 \%$ & $14,70 \%$ & $15,93 \%$ \\
\hline PT. Kimia Farma Tbk & $8,73 \%$ & $7,95 \%$ & $7,80 \%$ & $3,71 \%$ & $5,41 \%$ & $6,72 \%$ \\
\hline $\begin{array}{c}\text { T. Darya-Varia Laboratoria } \\
\text { Tbk }\end{array}$ & $10,62 \%$ & $6,58 \%$ & $7,85 \%$ & $9,96 \%$ & $9,89 \%$ & $8,98 \%$ \\
\hline
\end{tabular}


Sumber : Data diolah

Berdasarkan analisis sistem du pont selama rata-rata ROI sebesar 6,72\%, dan PT. Darya periode tahun 2013 - 2017 pada PT. Kalbe Varia Laboratoria Tbk mampu Farma Tbk mampu menghasilkan laba menghasilkan laba bersih setelah pajak dari bersih setelah pajak dari total aktiva total aktiva perusahaan dengan rata-rata perusahaan dengan rata-rata ROI sebesar ROI sebesar 8,98\%. Jika dilihat dari hasil 15,93\%, sedangkan PT. Kimia Farma Tbk rata-rata ROI, PT. Kalbe Farma Tbk mampu menghasilkan laba bersih setelah kembali lebih unggul dibandingkan dengan pajak dari total aktiva perusahaan dengan perusahaan lainnya.

Grafik 3

Perubahan Return On Investment Sampel Perusahaan

\begin{tabular}{|c|c|c|c|c|c|}
\hline \multirow{4}{*}{$\begin{array}{r}20,00 \% \\
15,00 \% \\
10,00 \% \\
5,00 \% \\
0,00 \%\end{array}$} & \multirow{3}{*}{\multicolumn{4}{|c|}{$r$}} & \\
\hline & & & & & \\
\hline & & & & & \\
\hline & 2013 & 2014 & 2015 & 2016 & 2017 \\
\hline PT. Kalbe Farma & $17,36 \%$ & $17,11 \%$ & $15,10 \%$ & $15,40 \%$ & $14,70 \%$ \\
\hline -PT. Kimia Farma & $8,73 \%$ & $7,95 \%$ & $7,80 \%$ & $3,71 \%$ & $5,41 \%$ \\
\hline $\begin{array}{l}\text { PT. Darya-Varia } \\
\text { Laboratoria Tbk }\end{array}$ & $10,62 \%$ & $6,58 \%$ & $7,85 \%$ & $9,96 \%$ & $9,89 \%$ \\
\hline
\end{tabular}

Sumber : Data diolah

\section{Equity Multiplier}

Menurut Arief Sugiono dan Edi Untung (2016:75)

"Equity Multiplier atau modal dibandingkan dengan total aktiva perusahaan atau seberapa besar aktiva dibiayai oleh hutang”.

menggambarkan seberapa besar ekuitas

$$
\text { Equity Multiplier }=\frac{\text { Total Aktiva }}{\text { Total Ekuitas }} \times 1 \mathrm{kqli}
$$

Tabel 6

Equity Multiplier Sampel Perusahaan

\begin{tabular}{|c|c|c|c|c|c|l|}
\hline Nama Perusahaan & 2013 & 2014 & 2015 & 2016 & 2017 & Rata-Rata \\
\hline PT. Kalbe Farma Tbk & $1,33 \mathrm{Kali}$ & $1,27 \mathrm{Kali}$ & $1,25 \mathrm{Kali}$ & $1,22 \mathrm{Kali}$ & $1,19 \mathrm{Kali}$ & $1,25 \mathrm{Kali}$ \\
\hline PT. Kimia Farma Tbk & $1,52 \mathrm{Kali}$ & $1,64 \mathrm{Kali}$ & $1,74 \mathrm{Kali}$ & $2,03 \mathrm{Kali}$ & $2,37 \mathrm{Kali}$ & $1,86 \mathrm{Kali}$ \\
\hline $\begin{array}{c}\text { PT. Darya-Varia Laboratoria } \\
\text { Tbk }\end{array}$ & $1,30 \mathrm{Kali}$ & $1,31 \mathrm{Kali}$ & $1,41 \mathrm{Kali}$ & $1,42 \mathrm{Kali}$ & $1,47 \mathrm{Kali}$ & $1,38 \mathrm{Kali}$ \\
\hline
\end{tabular}

Sumber : Data diolah 
Berdasarkan hasil analisis sistem du pont selama periode tahun 2013 - 2017, PT. Kalbe Farma Tbk mampu mengelola modal perusahaan dengan rata-rata sebesar 1,23 kali, PT. Kimia Farma Tbk mampu mengelola modal perusahaan dengan ratarata sebesar 1,86, dan PT. Darya-Varia Laboratoria Tbk mampu mengelola perusahaan dengan rata-rata sebesar 1,38 kali, hal ini dilakukan untuk menghasilkan pendapatan sehingga mampu meningkatkan aktiva pada perusahaan tersebut dan PT. Kimia Farma Tbk memiliki kemampuan mengelola modal nya lebih baik dibandingkan dengan perusahaan lainnya.

\section{Grafik 4}

\section{Perubahan Equity Multiplier Sampel Perusahaan}

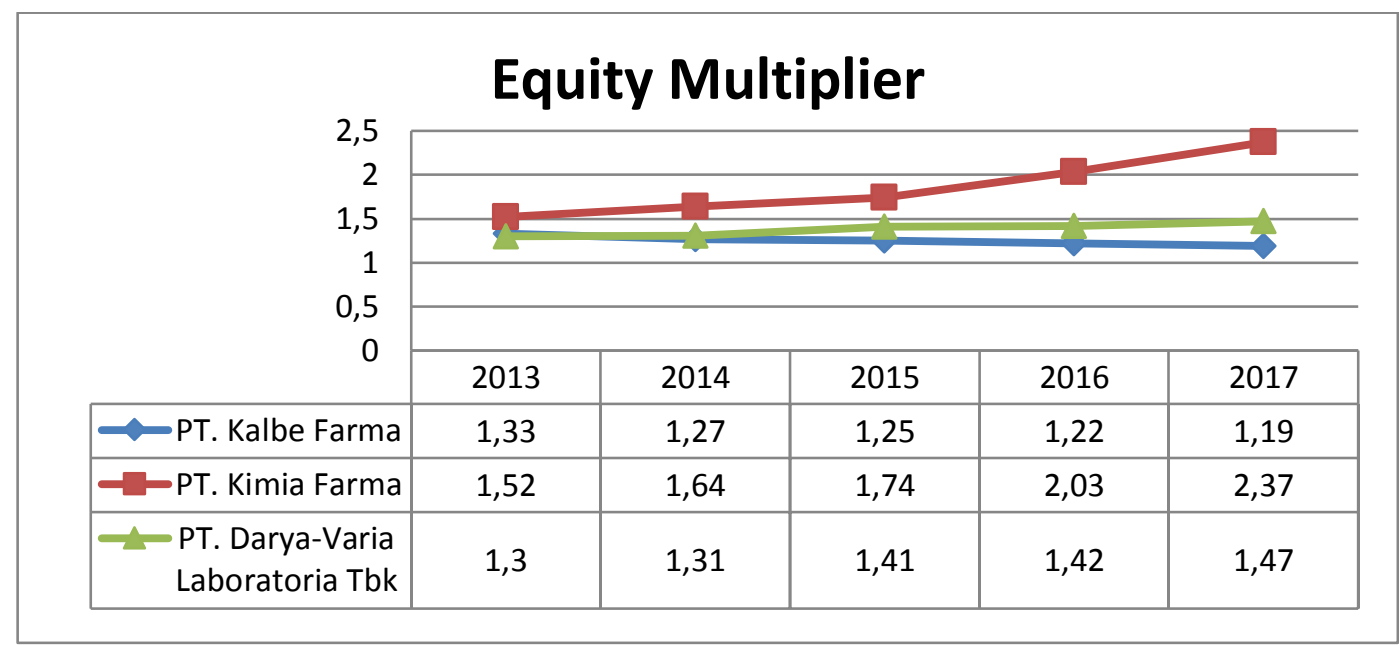

Sumber : Data diolah

\section{Return On Equity}

Menurut Arief Sugiono dan Edi Untung (2016:75) "Return On Equity adalah rasio yang mengukur tingkat pengembalian dari bisnis atas seluruh modal yang ada".

$R O E=R O I X$ Equity Multiplier

Tabel 7

Return On Equity Sampel Perusahaan

\begin{tabular}{|c|c|c|c|c|c|l|}
\hline Nama Perusahaan & 2013 & 2014 & 2015 & 2016 & 2017 & Rata-Rata \\
\hline PT. Kalbe Farma Tbk & $23,10 \%$ & $21,73 \%$ & $18,86 \%$ & $18,79 \%$ & $17,49 \%$ & $19,99 \%$ \\
\hline PT. Kimia Farma Tbk & $13,27 \%$ & $13,04 \%$ & $13,57 \%$ & $7,53 \%$ & $12,82 \%$ & $12,05 \%$ \\
\hline PT. Darya-Varia Laboratoria Tbk & $13,81 \%$ & $8,62 \%$ & $11,07 \%$ & $14,14 \%$ & $14,54 \%$ & $12,44 \%$ \\
\hline
\end{tabular}

Sumber : Data diolah 
Berdasarkan hasil analisis sistem du pont selama periode tahun 2013 - 2017, PT. Kalbe Farma mampu menghasilkan return on equity dengan rata-rata sebesar 19,99\%, sedangkan untuk PT. Kimia Farma Tbk mampu menghasilkan return on equity dengan rata-

Grafik 4

Perubahan Return On Equity Sampel Perusahaan

\begin{tabular}{|c|c|c|c|c|c|}
\hline \multirow{5}{*}{$\begin{array}{r}25,00 \% \\
20,00 \% \\
15,00 \% \\
10,00 \% \\
5,00 \% \\
0,00 \%\end{array}$} & \multicolumn{4}{|c|}{$\mathrm{r}$} & \\
\hline & \multirow{2}{*}{\multicolumn{5}{|c|}{$\mathrm{CON}$}} \\
\hline & & & & & \\
\hline & \multirow[b]{2}{*}{2013} & \multirow[b]{2}{*}{2014} & \multirow[b]{2}{*}{2015} & \multirow[b]{2}{*}{2016} & \multirow[b]{2}{*}{2017} \\
\hline & & & & & \\
\hline$\leadsto$ PT. Kalbe Farma & $23,10 \%$ & $21,73 \%$ & $18,86 \%$ & $18,79 \%$ & $17,49 \%$ \\
\hline -PT. Kimia Farma & $13,27 \%$ & $13,04 \%$ & $13,57 \%$ & $7,53 \%$ & $12,82 \%$ \\
\hline $\begin{array}{l}\text { PT. Darya-Varia } \\
\text { Laboratoria Tbk }\end{array}$ & $13,81 \%$ & $8,62 \%$ & $11,07 \%$ & $14,14 \%$ & $14,54 \%$ \\
\hline
\end{tabular}

Sumber : Data diolah

\section{Kesimpulan dan Saran}

\section{Kesimpulan}

1. Hasil Perhitungan Analisis Sistem Du Pont

a. PT. Kalbe Farma Tbk

Berdasarkan hasil perhitungan sistem du pont asset turn over tertinggi perusahaan sebesar 1,41 kali berada pada tahun 2013 dan selalu mengalami penurunan setiap tahunnya. Net profit margin perusahaan tertinggi berada pada tahun 2013 yaitu sebesar $12,31 \%$, hasil perhitungan return on rata sebesar 12,05\%, dan PT. Darya Varia Laboratoria Tbk mampu menghasilkan return on equity dengan rata-rata sebesar $12,44 \%$, hal ini menunjukan bahwa adanya efisiensi penggunaan modal perusahaan. 
Berdasarkan hasil perhitungan sistem du pont asset turn over tertinggi perusahaan berada pada tahun 2013 yaitu sebesar 1,76 kali dan selalu mengalami penurunan setiap tahunnya, hasil perhitungan net profit margin perusahaan tertinggi pada tahun 2017 yaitu sebesar 5,41\%, hasil perhitungan return on investment tertinggi pada tahun 2013 yaitu sebesar $8,73 \%$ selalu mengalami penurunan setiap tahunnya, hasil perhitungan equity multiplier perusahaan tertinggi berada pada tahun 2017 yaitu sebesar 2,37 kali dan selalu meningkat dari tahun sebelumnya, dan hasil perhitungan terakhir yaitu return on equity perusahaan tertinggi berada pada tahun 2015 yaitu sebesar $13,57 \%$.

\section{c. PT. Darya-Varia Laboratoria Tbk}

Berdasarkan hasil perhitungan sistem du pont menghasilkan asset turn over perusahaan tertinggi berada pada tahun 2017 yaitu sebesar 0,96 kali yang mengalami kenaikan dibandingkan dengan tahun sebelumnya, hasil perhitungan net profit margin perusahaan tertinggi pada tahun 2013 sebesar 11,42\% dan mengalami fluktuatif di tahun-tahun berikutnya, hasil perhitungan return on investment perusahaan tertinggi berada pada tahun 2013 yaitu sebesar 10,62\%, hasil perhitungan equity multiplier perusahaan tertinggi berada pada tahun 2017 yaitu sebesar 1,47 kali, dan hasil perhitungan terakhir yaitu return on equity perusahaan tertinggi berada pada tahun 2017 yaitu sebesar $14,54 \%$.
2. Bagaimana kinerja keuangan PT. Kalbe Farma Tbk, PT. Kimia Farma Tbk, dan PT. Darya-Varia Laboratoria Tbk jika diukur menggunakan metode du pont.

Dari hasil perhitungan ketiga perusahaan yang bergerak di sektor farmasi dimana PT. Kimia Farma Tbk yang dikelola oleh negara sedangkan PT. Kalbe Farma Tbk dan PT. Darya-Varia Laboratoria Tbk dikelola oleh swasta menunjukan bahwa PT. Kalbe Farma Tbk menghasilkan rata-rata return on equity yang paling besar selama periode 2013 - 2017 dibanding dengan kedua perusahaan lainnya. PT. Kalbe Farma Tbk menghasilkan rata-rata ROE sebesar 19,99\%, sedangkan PT. Darya-Varia Laboratoria Tbk menghasilkan rata-rata ROE sebesar 12,44\% dan PT. Kimia Farma Tbk menghasilkan rata-rata ROE sebesar $12,05 \%$, hal ini menunjukan bahwa PT. Kalbe Farma Tbk selama periode 2013 2017 memiliki kinerja keuangan yang lebih baik dibandingkan dengan PT. Darya-Varia Laboratoria Tbk dan PT. Kimia Farma Tbk.

\section{Saran}

Berdasarkan hasil perhitungan analisis menggunakan sistem du pont maka peneliti akan memberikan saran kepada perusahaan yang menjadi objek penelitian yaitu PT. Kalbe Farma Tbk, PT. Kimia Farma Tbk, dan PT. Darya-Varia Laboratoria Tbk.

Dilihat dari hasil perhitungan Return On Investment (ROI) dan Return On Equity (ROE), PT.

Kalbe Farma Tbk selalu mengalami penurunan setiap tahunnya. Untuk meningkatkan tingkat pengembalian pada asset atau modal nya, perusahaan dapat 
meminimalisasi biaya produksi, biaya operasional atau biaya lainnya, dan juga perusahaan dapat mencari alternatif pemasaran yang tepat sehingga dapat meningkatkan penjualan untuk mendapatkan keuntungan yang lebih besar lagi, dan untuk PT. Kimia Farma Tbk dan PT. Darya-Varia Laboratoria Tbk nilai Return On Investment (ROI) dan nilai Return On Equity (ROE) perusahaan mengalami fluktuatif setiap tahunnya, untuk meningkatkan tingkat pengembalian terhadap asset atau modal nya, perusahaan dapat meminimalisasi biaya produksi, biaya operasional atau biaya lainnya, dan juga perusahaan dapat mencari alternatif pemasaran yang tepat sehingga dapat meningkatkan penjualan untuk mendapatkan keuntungan yang lebih besar lagi dan dapat menarik para investor untuk menanamkan saham atau dana nya kedalam perusahaan.

Saran untuk penelitian selanjutnya:

1. Diharapkan dapat menambahkan metode analisis lain sebagai perbandingan analisis kinerja keuangan perusahaan.

2. Diharapkan dapat menambah kategori perusahaan yang dijadikan sampel penelitian, misalnya seluruh perusahaan yang terdaftar di BEI.

\section{Daftar Pustaka}

Azis Firdaus, M. (2016).

Metode Penelitian.

EDISI, 2.

Edy Untung, A. S. (2016).

Panduan Praktis Dasar

Analisa Laporan

Keuangan Edisi Revisi.

Grasindo. 